\title{
Antibodies to meningococcal class 1 outer-membrane protein and its variable regions in patients with systemic meningococcal disease
}

\author{
I. IDÄNPÄÄN-HEIKKILÄ, E. A. HØIBY*, P. CHATTOPADHYAY, U. AIRAKSINEN, \\ T. M. MICHAELSEN $\dagger$ and E. WEDEGE $\dagger$
}

Department of Bacterial Vaccine Research and Molecular Bacteriology, National Public Health Institute, Mannerheimintie 166,00300 Helsinki, Finland, "Department of Bacteriology and $\dagger$ Department of Vaccinology, National Institute of Public Health, Geitmyrsveien 75, N-0462 Os/o, Norway

\begin{abstract}
Summary. Antibodies to the meningococcal serosubtype-specific P1.7,16 protein and its variable regions (VR) were analysed in 28 convalescent sera drawn 8-36 months after systemic meningococcal disease by immunoblotting and enzyme immunoassay (EIA) methods. EIA antigens were the meningococcal P1.7,16 protein, produced in Bacillus subtilis, and peptides covering its VR1 (P1.7 region) and VR2 (P1.16 region) inserted into a bacterial penicillinase protein. In the immunoblotting method, three meningococcal reference strains were used; they expressed either the P1.7,16 protein, or only its VR1 or VR2 epitopes in their class 1 proteins. Both methods showed a strong IgG response in four sera to P1.7,16 and VR2, but not to VR1; 18 sera had no or weak anti-class 1 protein activity. The six remaining sera were positive only on blots. The VR2-specific sera had 30-fold higher bactericidal activity than those with negligible P1.7,16 responses. Previous vaccination of the patients with a B: 15:P1.7,16 meningococcal vaccine was associated with a strong anti-P1.7,16 and anti-VR2 booster response that declined with time. The subtype-specific antibody activity in some sera indicated colonisation after disease by meningococci with class 1 proteins different from the strain that had caused disease.
\end{abstract}

\section{Introduction}

The class 1 protein, encoded by the por $A$ gene, is a major outer-membrane protein of Neisseria meningitidis and is expressed by most meningococcal isolates. ${ }^{1,2}$ Antigenic variations of the class 1 protein generate the serosubtype-specificity of meningococci. ${ }^{2}$ Comparison of por $A$ genes and their deduced aminoacid sequences showed that this diversity is confined to two distinct variable regions, designated VR1 and VR2. ${ }^{3-7}$ Sequence information has led to a proposed topology of the class 1 protein with membranespanning $\beta$-strands intervened by surface-exposed loop structures. ${ }^{5,8}$ Epitope mapping studies have localised the VR1 and VR2 regions to the apices of loops 1 and 4, respectively., 7-9 Binding of subtypespecific monoclonal antibodies (MAbs) to these regions has been shown to be bactericidal in vitro and protective in an in-vivo animal model..$^{10,11}$ Loops 1 and 4 are immunodominant and induce bactericidal

Received 20 March 1995; accepted 18 April 1995. $\ddagger$ Correspondence should be sent to Dr E. Wedege. antibodies in mice immunised with whole bacteria. ${ }^{12,13}$ Also, antisera raised by immunisation of rabbits with a cyclic peptide containing the surface-exposed loop 4 are bactericidal. ${ }^{14}$

After immunisation of human volunteers with different meningococcal outer-membrane vesicle (OMV) vaccines, the serum bactericidal activity appears to be associated with class 1 protein antibodies. $^{15,16}$ In a group of volunteers receiving a B:15:P1.7,16 OMV vaccine, the class 1 antibody response was mainly directed against the P1.16 determinant in VR2. ${ }^{17,18}$ The class 1 protein antibodies in these vaccines contributed significantly to the serum bactericidal activity. ${ }^{18,19}$

In those studies, the VR specificity of the class 1 protein antibodies was scored on immunoblots with reference meningococci as antigens that expressed either the VR1 or VR2 of the P1.7,16 protein in their class 1 proteins. ${ }^{17,18}$ Recently, the VR1 and VR2 regions of $P 1.7,16$ have been inserted into a bacterial carrier protein, the penicillinase of Bacillus licheniformis (Airaksinen et al., unpublished data). The current study investigated whether similar results for 
the VR responses would be obtained and better quantitated in enzyme immunoassays (EIA) with these epitope-specific antigens and a recombinant P1.7,16 protein devoid of other meningococcal components. For this analysis, a set of late convalescent sera from patients with systemic meningococcal disease who participated in the Norwegian vaccine trial either as vaccinees, placebo controls or non-participants were used. ${ }^{20}$ The aim of this study was to compare the serum antibody levels in immunoblotting and EIA assays against P1.7,16 and its VR1 and VR2, and then to determine the association between these antibody responses and the bactericidal titres of the sera.

\section{Materials and methods}

\section{Meningococcal strains}

Reference strains 44/76 (B:15:P1.7,16), M1080 (B:1:P1.7,1), S3032 (B:NT:P1.12,16) and H355 (B: 15:P1.15) ${ }^{2}$ were used as antigens for immunoblotting; strains IH5341 (B:15:P1.7,16) and H355 (B: 15:P1.15) were used for whole-cell preparations and cloning of por $A$ genes. ${ }^{21}$ Other strains were characterised by dot-blotting with MAbs from Drs J. T. Poolman, RIVM, Bilthoven, The Netherlands and W. D. Zollinger, Walter Reed Army Institute of Research, Washington, DC, USA, as previously reported. ${ }^{22}$

\section{Human sera}

The sera for this study were selected from a collection of 99 late convalescent sera, drawn at least 6 months after systemic meningococcal disease, from participants in the Norwegian group B vaccination trial. ${ }^{23}$ All 99 sera were screened on immunoblots for binding to OMV from the vaccine strain $44 / 76$ in the absence and presence of Empigen BB (Albright and Wilson, Cumbria) $0.15 \%$, a detergent used for refolding of denatured antigens on blots. ${ }^{24,25}$ Twentyeight sera were selected by the following criteria: (1) all with distinct antibody binding to $\mathrm{P} 1.7,16$ protein on blots; (2) detergent-dependent P1.7,16 binding; (3) weak binding, but infection with a vaccine-like strain. The patients were identified by their K-numbers ${ }^{26}$ and all had apparently normal complement function. ${ }^{23}$ Eight of the patients had been vaccinated twice in 1988-89 with the OMV vaccine, eight had received aluminium hydroxide placebo vaccine, and 12 belonged to the non-participant group. ${ }^{20}$ Sera drawn 8-79 days after onset of disease (early convalescent sera) from 12 of the vaccinees and placebo controls were also analysed.

\section{EIA antigens}

Recombinant class 1 proteins. Recombinant class 1 proteins BacP1.7,16 $6^{21}$ and $\mathrm{BacP} 1.15^{27}$ were produced in $B$. subtilis. Briefly, por $A$ genes encoding protein
$\mathrm{P} 1.7,16$ in strain $\mathrm{IH} 5341$ and protein $\mathrm{P} 1.15$ in strain $\mathrm{H} 355$ were cloned in the plasmids pKTH290 and pKTH3115, respectively. B. subtilis strains IH6627 and IH6646, containing these plasmids and expressing the class 1 proteins as inclusion bodies (BacP1), were grown to stationary phase in liquid culture containing kanamycin $30 \mu \mathrm{g} / \mathrm{L}$. After harvesting, cells were treated with lysozyme, and BacPl was isolated by centrifugation before washing with NP-40 $1 \%{ }^{21}$ The inclusion bodies were solubilised in sodium dodecyl sulphate (SDS) $1 \%$.

$V R 1$ and VR2 peptides. Construction of the plasmids pKTH3141 and pKTH3152, encoding the VR2 (P1.16) and VR1 (P1.7) regions from protein $\mathrm{P} 1.7,16$ inserted into the bacillar penicillinase as a carrier protein, and their expression in B. subtilis will be described in detail elsewhere (Airaksinen et al., unpublished data). Briefly, a DNA fragment encoding amino acids $17-295^{28}$ of the $\beta$-lactamase (Bla) from $B$. licheniformis 749 /C was generated by polymerase chain reaction (PCR) and ligated into the HindIII site of the secretion vector pKTH132. ${ }^{29}$ An oligonucleotide encoding VR2 region AYYTKDTNNNLTLVPAVVGK of P1.7,16 porA gene was inserted between the codons corresponding to 254 (Pro) and 258 (Pro) of Bla to generate pKTH3141. The part of the same por $A$ gene encoding VR1 region QLQLTEAQAANGGASGQVKVTKVTKA was generated by the PCR and inserted in the same site of Bla (pKTH3152). Bla-VR1 and Bla-VR2 fusion proteins were found to be secreted. The fusion proteins, used as coating antigens in EIA, were purified by a two-step precipitation procedure with ammonium sulphate $(65 \%$ and $80 \%$ saturation) dialysed against $50 \mathrm{~mm}$ Tris $\mathrm{HCl}, \mathrm{pH} \mathrm{7}$, and proteins other than BlaVR1 and Bla-VR2 were removed by adsorption to DEAE-Sepharose (Pharmacia Biotech, Sweden).

Meningococcal whole-cell preparations. Whole cell preparations were made from strains IH5341 and H355 as described previously. ${ }^{21.27}$

\section{Detection of immune response}

Immunoblotting. $\mathrm{OMV}^{30}$ from the four reference strains 44/76, M1080, S3032 and H355 and whole-cell suspensions of other meningococci were boiled in sample buffer containing SDS and separated in acrylamide $12 \%$ gels. $^{22}$ After electrotransfer, nitrocellulose filters were incubated overnight with 1 in 200 dilutions of human sera as described previously. ${ }^{15}$ All sera were incubated with and without Empigen $\mathrm{BB}$ $0.15 \%{ }^{25}$ IgG binding was detected with a 1 in 500 dilution of rabbit anti-human IgG conjugated to horseradish peroxidase (Dakopatts a/s, Denmark). The intensity of $\operatorname{IgG}$ binding to class 1 proteins was scored visually on a scale from 0 to 4 , where scores of 0-1.5 represented no or weak binding, 2-2.5 medium binding and 3-4 strong binding. The data presented are those obtained without Empigen BB; when the results with Empigen BB differed from those without it, this is indicated specifically. 
EIA. This was performed as described earlier. ${ }^{21}$ Briefly, flat-bottomed microtitration plates (Nunc, Roskilde, Denmark) were coated overnight at $37^{\circ} \mathrm{C}$ with protein $5 \mu \mathrm{g} / \mathrm{ml}$ in phosphate-buffered saline (PBS). Stock solutions of BacP1.7,16 and BacP1.15 were kept at $1.6 \mathrm{mg} / \mathrm{ml}$ in SDS $0.1 \%$. Sera and alkaline phosphatase-conjugated antibodies to human immunoglobulins IgG, IgM and IgA (Caltag Laboratories, San Francisco, CA, USA) were diluted in PBS containing fetal calf serum (Gibco, Paisley) $10 \%$. Titres were expressed as sample dilutions that gave $\mathrm{E}=0.3$ measured at $405 \mathrm{~nm}$ after incubation for $30 \mathrm{~min}$. The lowest serum dilution tested was in 1 in 100 . Titres $<1000$ indicated no or minor antibody activity, while titres of 1000-1500 represented low antibody levels.

\section{Bactericidal assay}

Serum bactericidal activity was assayed in microtitration plates as described previously. ${ }^{19}$ The wells contained two-fold dilutions of serum (starting at serum $50 \%$ ), an inoculum of $70-80 \mathrm{cfu}$ of strain $44 / 76$ (B: 15:P1.7,16) and human complement $25 \%$. The complement source gave no fall in cfu in the test strain after incubation for $30 \mathrm{~min}$; and it showed no reaction with OMV from strain $44 / 76$ on immunoblots. About $10 \%$ of the colonies of strain $44 / 76$ expressed Opc. ${ }^{31}$ Titres are given as the final serum dilution that gave $>50 \%$ killing of the inoculum. A titre of $<2$ was assigned to sera with $<50 \%$ killing at a 1 in 2 dilution. A positive standard serum was included in every second plate.

\section{Results}

Characterisation of the immune response to the class 1 protein

Immune responses to the $\mathrm{P} 1.7,16$ protein in 28 convalescent sera, drawn 8-36 months after invasive meningococcal disease, were characterised by EIA with three coating antigens: (1) denatured recombinant BacP1.7,16 produced in B. subtilis, (2) the $\mathrm{P} 1.7$ region from protein $\mathrm{P} 1.7,16$ inserted into the Bla carrier protein (Bla-VR1) and (3) the corresponding insert of the P1.16 region (Bla-VR2). Control antigens included the denatured recombinant BacP1.15 protein, expressing different subtypes in its VRs, and Bla without inserts. None of these antigens contained other components of meningococcal origin. EIA was performed with immunoglobulin class-specific reagents, but only IgG and not IgA or IgM antibodies to any of the above antigens were detected.

All sera were also analysed on immunoblots for their IgG antibody binding to denatured class 1 proteins in OMVs from four different strains. These were: (1) protein P1.7,16 from strain 44/76, (2) protein P1.7,1 from strain M1080 sharing the VR1-associated P1.7 subtype epitope with P1.7,16, (3) protein P1.12,16 from strain S3032 sharing the VR2-associated P1.16 subtype epitope with P1.7,16, and (4) P1.15 from strain H355 having no surface-exposed epitopes in common with P1.7,16. As in EIA, the latter strain served as control for the subtype specificity of the antibody responses. The intensities of the immunoreactive class 1 bands were scored as described in Materials and methods.

The results obtained with the two methods were classified into three groups as shown in table I. Group 1 included four sera for which both methods gave identical and strong antibody responses, group 2 contained 18 sera that showed no or low antibody binding to protein P1.7,16 with both methods and group 3 contained six sera that were positive by immunoblotting only.

The four sera in group 1 showed a high titre in EIA (range 3500-15000) with BacP1.7,16 protein. They also had high titres to Bla-VR2 (range 2400-7400), but none reacted with Bla-VR1. On blots, the same four sera reacted strongly (Scores 3.5-4) with both the P1.7,16 and P1.12,16 proteins, but not with the P1.7,1 protein, indicating that the main antibody activity recognised the P1.16 epitope in VR2 that was common to these two proteins. Thus, the results were fully parallel to those obtained in EIA. Lack of reaction with protein P1.15 in both methods (not shown in table I) also supported the subtype specificity of the IgG response.

Three of the patients in group 1 had been vaccinated 6-16 months before disease with the B:15:P1.7,16 OMV vaccine, whereas one patient (K-194) had received the placebo vaccine (table I). Two of the patients had been infected with vaccine-like strains, another with a strain of different subtype (B: 15:P1.12,13a), ${ }^{32}$ and one with a strain not isolated by culture but shown by other assays to be serogroup B. ${ }^{26}$

Sixteen of the 18 sera in group 2 showed no antiP1.7,16 activity in EIA (table I). Serum from patient K-106 displayed a low to medium titre with BacP1.7,16, Bla-VR1 and VR2. This serum also reacted with both BacP1.15 and Bla, indicating the presence of cross-reactive antibodies. The other serum with low BacP1.7,16 titre was drawn 8 months after disease from vaccinee $\mathrm{K}-217$ infected with a vaccinelike strain. All 18 sera showed no or weak binding to the different subtype proteins in immunoblots (scores $0-1.5$ with the three class 1 proteins). When incubated in the presence of the detergent Empigen BB, four of the group 2 sera (K-99, K-158, K-172 and K-188) bound with medium intensity to one or more of the class 1 proteins of the test strains. These strictly detergent-dependent antibody activities were probably directed against conformational epitopes on the class 1 proteins.

In conclusion, although 11 of the 18 patients in group 2, including two vaccinees, had been infected with vaccine-like strains expressing P1.7 or P1.16 epitopes, no or weak P1.7,16 antibody levels were 
Table I. IgG reaction of late convalescent sera with class 1 proteins and their VRs analysed by EIA and immunoblotting (IB)

\begin{tabular}{|c|c|c|c|c|c|c|c|c|c|c|}
\hline \multirow{2}{*}{ Group } & \multirow{2}{*}{$\begin{array}{l}\text { Patient } \\
\text { K-no. }\end{array}$} & \multirow{2}{*}{ Disease isolate } & \multirow{2}{*}{ Status +} & \multirow{2}{*}{$\begin{array}{l}\text { Time of } \\
\text { sampling } \\
\text { (months)§ }\end{array}$} & \multicolumn{3}{|c|}{ EIA titre $\|$} & \multicolumn{3}{|c|}{ IB score $\|$} \\
\hline & & & & & $\begin{array}{c}\text { Bac- } \\
\text { P1.7,16 }\end{array}$ & $\begin{array}{l}\text { Bla-VR1 } \\
\text { (P1.7) }\end{array}$ & $\begin{array}{c}\text { Bla-VR2 } \\
(\mathrm{P} 1.16)\end{array}$ & $\mathrm{P} 1.7,16$ & P1.7,1 & P1.12,16 \\
\hline \multirow{4}{*}{$\begin{array}{l}\text { Group 1 } \\
\text { IB + /EIA + }\end{array}$} & 15 & $\mathrm{~B}: 15: \mathrm{P} 1.17 .16 \mathrm{c}^{*}$ & V & 31 & 3500 & - & 2400 & 4 & - & 3.5 \\
\hline & 80 & $\mathrm{~B}: 15: \mathrm{P} 1.12,13 \mathrm{a}$ & V & 24 & 15000 & - & 3500 & 4 & - & 4 \\
\hline & 131 & $\mathrm{~B}: 15: \mathrm{P} 1.7 .16$ & V & 19 & 11200 & - & 7400 & 4 & - & 4 \\
\hline & 194 & $\mathrm{~B}: \dagger$ & $\mathbf{P}$ & 11 & 10600 & - & 3500 & 4 & - & 4 \\
\hline \multirow{18}{*}{$\begin{array}{l}\text { Group } 2 \\
\text { IB-/E1A- }\end{array}$} & 22 & $\mathrm{~B}: 15: \mathrm{P} 1.7,16$ & NP & 31 & - & - & - & - & - & - \\
\hline & 34 & B: $15:$ P $1 .(7), 16^{*}$ & NP & 28 & - & - & - & - & - & -- \\
\hline & 61 & B: $15: P 1.7,16$ & NP & 25 & - & - & - & - & - & - \\
\hline & 84 & B : $4:-$ & $\mathrm{V}$ & 23 & - & - & - & - & - & - \\
\hline & 87 & $\mathrm{C}: \dagger$ & NP & 23 & - & - & - & - & - & - \\
\hline & 99 & $\mathrm{~B}: 15: \mathrm{Pl}(7), 16^{*}$ & $\mathbf{P}$ & 22 & - & - & - & - & - & - \\
\hline & 104 & $\mathrm{C}: 2 \mathrm{a}: \mathrm{P} 1.2$ & NP & 22 & - & - & - & - & - & - \\
\hline & 106 & $\mathrm{~B}: 15: \mathrm{P} 1.12 .13 \mathrm{a}$ & $\mathrm{V}$ & 22 & 1200 & 1700 & - & - & - & - \\
\hline & 138 & $\mathrm{~B}: 15: \mathrm{P} 1.7,16$ & NP & 17 & - & - & - & - & - & - \\
\hline & 156 & $\mathrm{~B}: 15: \mathrm{P} 1.7,16$ & $\mathrm{~V}$ & 15 & - & - & - & - & - & - \\
\hline & 158 & $\mathrm{~B}: 15: \mathrm{P} 1.7,16$ & NP & 16 & - & - & - & - & - & - \\
\hline & 172 & B: $15: P 1.7,16$ & $\mathrm{P}$ & 13 & - & - & - & - & - & - \\
\hline & 177 & B:NT:P1.16 & $\mathbf{P}$ & 24 & - & - & - & - & - & - \\
\hline & 188 & $B:+$ & $\mathbf{P}$ & 11 & - & - & - & - & - & - \\
\hline & 198 & $\mathrm{~B}: 15: \mathrm{P} 1.7 .16$ & NP & 10 & - & - & - & - & - & - \\
\hline & 205 & $\mathrm{~B}: 15: \mathrm{P} 1.2,5$ & $\mathrm{P}$ & 9 & - & - & - & - & - & - \\
\hline & 209 & $\mathrm{C}: 2 \mathrm{~b}: \mathrm{P} 1.2$ & NP & 8 & - & - & - & - & -- & - \\
\hline & 217 & $\mathrm{~B}: 15: \mathrm{P} 1.7,16$ & $\mathrm{~V}$ & 8 & 1200 & - & - & - & - & - \\
\hline \multirow{6}{*}{$\begin{array}{l}\text { Group } 3 \\
\text { IB + /EIA - }\end{array}$} & 4 & $\mathrm{~B}: 15: \mathrm{P} 1.7,16$ & NP & 36 & - & - & - & 3 & - & - \\
\hline & 57 & $\mathrm{~B}: 15: \mathrm{P} 1.7$ & $\mathbf{P}$ & 25 & - & - & - & - & - & $3 \cdot 5$ \\
\hline & 66 & $\mathrm{~B}: 15: \mathrm{P} 1.7 .16$ & NP & 24 & - & - & - & $2 \cdot 5$ & $2 \cdot 5$ & $2 \cdot 5$ \\
\hline & 186 & $\mathrm{C}: 2 \mathrm{a}: \mathrm{P} 1.2$ & $\mathbf{P}$ & 11 & - & - & - & 2 & $3 \cdot 5$ & - \\
\hline & 187 & B: 15:P1.(7).16* & $\mathrm{V}$ & 11 & - & - & - & 2 & - & 2 \\
\hline & 223 & B: $4:$ P1.14 & NP & 8 & - & - & - & 3 & - & 3 \\
\hline
\end{tabular}

${ }^{*} \mathrm{Pl} 1.16 \mathrm{c}$ designates a $\mathrm{P} 1.16$ subtype variant ${ }^{18}$ and $\mathrm{Pl}$ (7) a masked $\mathrm{Pl} .7$ epitope. $^{33}$

†Culture-negative isolates with serological serogroup determination. ${ }^{26}$

$\pm V$. vaccinees; $P$. placebo controls; NP, non-participants.

$\S$ Months between onset of disease and sampling of late convalescent sera

All EIA titres $\leqslant 1000$ and IB scores $\leqslant 1.5$ are designated by - .

found by both methods in sera obtained 8-31 months after disease.

The six sera in group 3 showed no activity in EIA, but reacted on immunoblots with the class 1 protein of one or more of the three test strains with scores of 2-3.5 (table I). To obtain more information about the specificity of the class 1 protein response in these sera, they were also probed with other strains as shown in the figure. A representative for the group 1 sera with a VR2 (P1.16) response is included for comparison in panel $\mathrm{A}$. This serum (K-131) reacted with all class 1 proteins expressing the P1.16 epitope, including those with an unknown VRI. One of these strains reacted with a MAb against a conformational epitope (P1C) present on most class 1 proteins. ${ }^{22}$ No reaction was seen with the P1.7.1 and P1.12,13a proteins. Serum from patient K-66 (panel B) bound to all class 1 proteins expressing subtypes $\mathrm{P} 1.16$ or $\mathrm{P} 1.7$, but not to $\mathrm{Pl} 1.2$ or P1.15 subtype proteins. This indicated that the IgG antibodies recognised both the P1.7 and P1.16 regions on the $P 1.7 .16$ protein, but not other structures on the class 1 proteins. Compared to the serum from patient K-131, that from patient K-187 (panel C) showed a similar, but weaker binding to the P1.7,16 and $\mathrm{P} 1.12,16$ proteins, as well as to the other P1.16 proteins (not shown).
Also serum from patient K-223 (panel D) reacted with both P1.7,16 and P1.12,16, indicating antibodies against subtype P1.16. However, this serum did not bind to P1.16 subtype proteins with unknown VR1 epitopes (panel D, lanes 5 and 6), in contrast to that shown by the other sera with P1.16 antibody activity. This binding pattern suggested that the serum recognised that $\mathrm{P} 1.16$ epitope only in combination with certain VR1s. Serum from patient K-4 bound strongly to $\mathrm{P} 1.7,16$, but not to the other class 1 proteins (table $I$ and panel $E$ in the figure). Identical results were obtained when detergent was used for renaturation of the antigens. Because this serum showed no reaction with $\mathrm{BacP} 1.7,16$ in EIA, the antibodies might be directed against conformational epitopes on the $\mathrm{P} 1.7,16$ protein which were partially renatured in the absence of detergent during the blotting procedure.

In contrast to the various antibody specificities in these sera directed to different parts on P1.7,16, serum from patients K-57 and K-186 showed other subtypespecificities. Serum from patient K-57 bound only to P1.12,16 and P1.12,13a (figure, panel F). Therefore, its reaction with $P 1.12,16$, shown in table $I$, was accounted for by antibodies against the P1.12 epitope expressed by these two strains. The binding of serum 


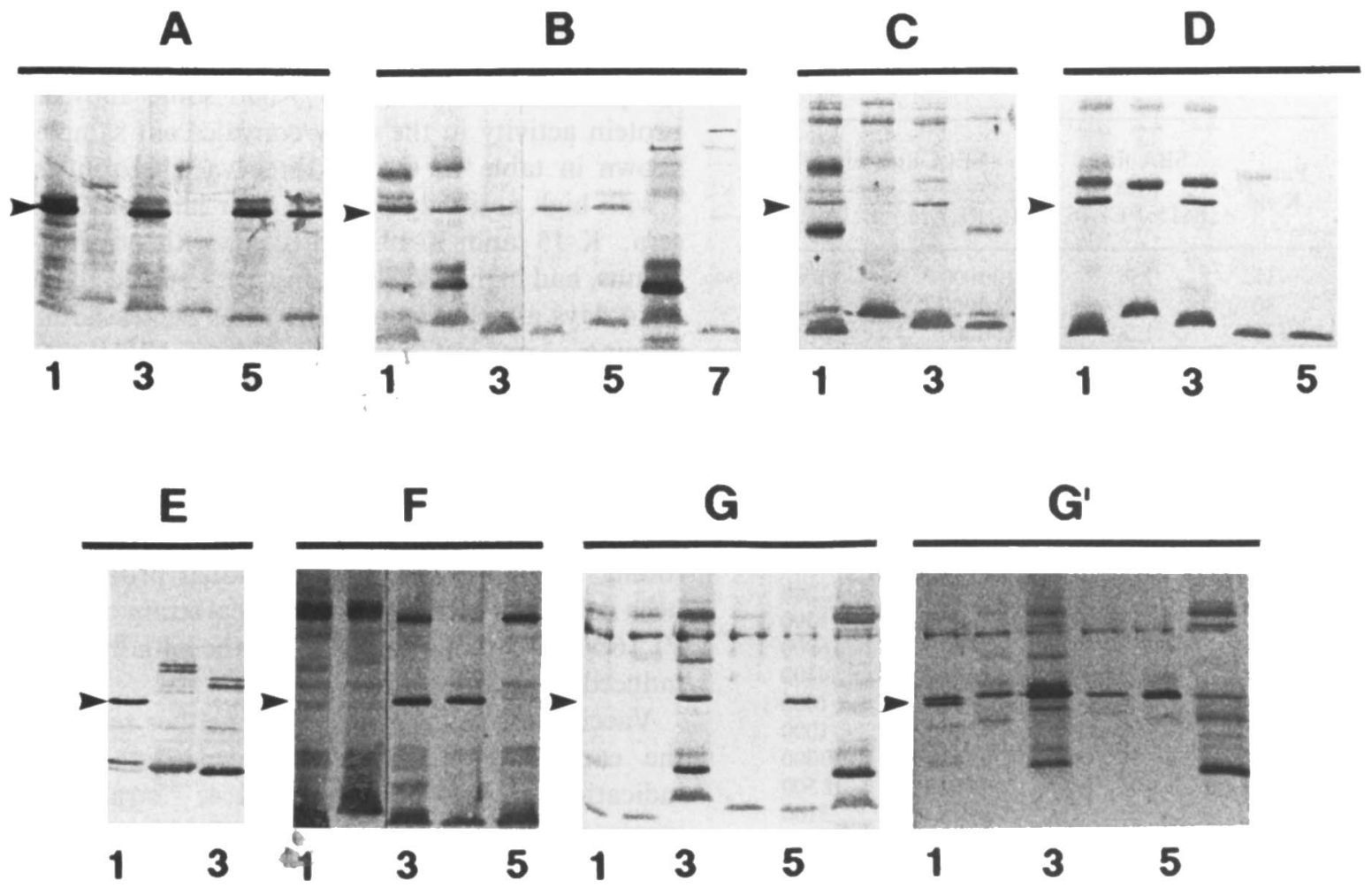

Figure. Immunoblots showing class 1 protein antibody specificities of late convalescent sera from patients with meningococcal disease. Panels show IgG binding of sera in group $1(\mathbf{A})$ and group $3\left(\mathbf{B}-\mathbf{G}^{\prime}\right)$ (see table I) to class 1 proteins from different meningococci. A, serum from patient K-131 incubated with: $1, \mathrm{~B}: 15: \mathrm{P} 1.7,16 ; 2, \mathrm{~B}: 1: \mathrm{P} 1.7,1 ; 3, \mathrm{~B}: \mathrm{NT}: \mathrm{P} 1.12,16 ; 4,15: \mathrm{P} 1.12,13 \mathrm{a} ; 5, \mathrm{~B}: \mathrm{NT}: \mathrm{P} 1.16, \mathrm{P} 1 \mathrm{C}+; 6, \mathrm{~B}: \mathrm{NT}: \mathrm{P} 1.16, \mathrm{P} 1 \mathrm{C}-$. $\mathrm{P} 1 \mathrm{C}+/$ - designates reactions with MAb (supplied by $\mathrm{Dr} \mathrm{W}$. D. Zollinger) against a common class 1 protein determinant. B, serum from patient K-66 incubated with: 1, B:15:P1.7,16; 2, B:1:1.7,1; 3, B:NT:P1.12,16; 4, B:NT:P1.16,P1C-; 5, B:15:P1.7,2; 6, C:2a:P1.2; 7, B:15:P1.15. C, serum from patient K-187 incubated with: 1, B:15:P1.7,16; 2, B:1:P1.7,1; 3, B:NT:P1.12,16; 4, B:15:P1.12,13a. D, serum from patient K-223 incubated with: 1, B:15:P1.7,16; 2, B:1:P1.7,1; 3, B:NT:P1.12,16; 4, B:NT:P1.16,P1C+; 5, B:NT:P1.16,P1C - . E, serum from patient K-4 incubated with: 1, B:15:P1.7,16; 2, B:1:P1.7,1; 3, B:NT:P1.12,16. F, serum from patient K-57 incubated with: 1, B:15:P1.7,16; 2, B:1:P1.7,1; 3, B:NT:P1.12,16; 4, B:15:P1.12,13a; 5, B:15:P1.15. G, serum from patient K-186 incubated with: 1, C:2a:P1.2;2, B:15:P1.7,16;3, B:1:P1.7,1;4, B:NT:P1.12,16;5, B:15:P1.1,15;6, B:15:P1.15. G', As in panel G, but incubation performed with Empigen BB $0 \cdot 15 \%$ to increase antigen renaturation. ${ }^{25}$ Positions of class 1 proteins are shown by arrows. Whole-cell suspensions of meningococci, boiled with sample buffer before electrophoresis, served as antigens, and IgG binding was detected with peroxidase-conjugated antibodies.

Table II. IgG reactions of early and late convalescent sera with protein P1.7,16 and VR2

\begin{tabular}{|c|c|c|c|c|c|c|c|}
\hline \multirow[b]{2}{*}{ Group } & \multirow[b]{2}{*}{$\begin{array}{c}\text { Patient } \\
\text { K-no. }\end{array}$} & \multirow{2}{*}{ Disease isolate } & \multirow{2}{*}{ Status } & \multirow{2}{*}{$\begin{array}{l}\text { Time of } \\
\text { sampling }\end{array}$} & \multirow{2}{*}{$\begin{array}{l}\text { IB score } \\
\text { for } \\
\text { P1.7,16 }\end{array}$} & \multicolumn{2}{|c|}{ EIA titres } \\
\hline & & & & & & BacP1.7,16 & $\begin{array}{c}\text { Bla-VR2 } \\
(\mathrm{P} 1.16)\end{array}$ \\
\hline \multirow[t]{3}{*}{ Group 1} & $\mathrm{~K}-15$ & $\mathrm{~B}: 15: \mathrm{P} 1.7,16 \mathrm{c}$ & V & $\begin{array}{l}8 \text { days } \\
31 \text { months }\end{array}$ & $\begin{array}{l}4 \\
3 \cdot 5\end{array}$ & $\begin{array}{r}185600 \\
3500\end{array}$ & $\begin{array}{r}53900 \\
2400\end{array}$ \\
\hline & $\mathrm{K}-80$ & $\mathrm{~B}: 15: \mathrm{P} 1.12,13 \mathrm{a}$ & $\mathrm{v}$ & $\begin{array}{l}45 \text { days } \\
24 \text { months }\end{array}$ & $\overline{4}$ & $\overline{15000}$ & - \\
\hline & K-131 & $\mathrm{B}: 15: \mathrm{P} 1.7,16$ & $\mathrm{~V}$ & $\begin{array}{l}14 \text { days } \\
19 \text { months }\end{array}$ & $\begin{array}{l}4 \\
4\end{array}$ & $\begin{array}{l}39800 \\
11200\end{array}$ & $\begin{array}{r}32800 \\
7400\end{array}$ \\
\hline \multirow[t]{3}{*}{ Group 2} & $\mathrm{~K}-84$ & B: $4:-$ & V & $\begin{array}{l}43 \text { days } \\
23 \text { months }\end{array}$ & - & $\begin{array}{l}- \\
-\end{array}$ & $\begin{array}{l}- \\
-\end{array}$ \\
\hline & K-177 & B:NT:P1.16 & $\mathrm{P}^{*}$ & $\begin{array}{l}9 \text { days } \\
12 \text { days } \\
24 \text { months }\end{array}$ & $\begin{array}{l}3 \\
3 \\
-\end{array}$ & $\begin{array}{l}4200 \\
5500 \\
-\end{array}$ & $\begin{array}{l}- \\
1200 \\
-\end{array}$ \\
\hline & K-217 & B: $15: P 1.7,16$ & $\mathrm{~V}$ & $\begin{array}{l}18 \text { days } \\
8 \text { months }\end{array}$ & 4 & $\begin{array}{c}43300 \\
-\end{array}$ & $\begin{array}{c}22500 \\
-\end{array}$ \\
\hline Group 3 & K-187 & B: $15: P 1 .(7), 16$ & V & $\begin{array}{l}12 \text { days } \\
11 \text { months }\end{array}$ & $\begin{array}{l}4 \\
2\end{array}$ & $\begin{array}{c}12300 \\
-\end{array}$ & $\begin{array}{c}4900 \\
-\end{array}$ \\
\hline
\end{tabular}

For explanations, see table I.

*None of the early convalescent sera from the other five placebo controls studied (K-57, K-99, $\mathrm{K}-172, \mathrm{~K}-188$ and $\mathrm{K}-205$ ) had any $\mathrm{P} 1.7,16$ or VR2 responses. 
Table III. Antibody responses of late convalescent sera to meningococcal surface antigens as assayed by serum bactericidal activities (SBA) and EIA with whole meningococci

\begin{tabular}{|c|c|c|c|c|}
\hline \multirow{2}{*}{ Group } & \multirow{2}{*}{$\begin{array}{l}\text { Patient } \\
\text { K-no. }\end{array}$} & \multirow{2}{*}{$\begin{array}{c}\text { SBA titre } \\
\text { with } \\
\text { B: } 15: \text { P1.7,16 }\end{array}$} & \multicolumn{2}{|c|}{ EIA titre with } \\
\hline & & & $\mathrm{B}: 15: \mathrm{P} 1.7,16$ & B: $15: P 1.15$ \\
\hline \multirow[t]{4}{*}{ Group 1} & 15 & 256 & 100000 & 30000 \\
\hline & 80 & 512 & 116000 & 30000 \\
\hline & 131 & 128 & 100000 & 10000 \\
\hline & 194 & 256 & 300000 & 91000 \\
\hline \multirow[t]{18}{*}{ Group 2} & 22 & 64 & 10300 & 6400 \\
\hline & 34 & 8 & 7400 & 5000 \\
\hline & 61 & 4 & 116000 & 1000 \\
\hline & 84 & 2 & 21300 & 15000 \\
\hline & 87 & $<2$ & 59000 & 5400 \\
\hline & 99 & $<2$ & 27000 & 13500 \\
\hline & 104 & 8 & 10000 & 2700 \\
\hline & 106 & 2 & 40000 & 12200 \\
\hline & 138 & 4 & 6400 & 1300 \\
\hline & 156 & 128 & 57000 & 6800 \\
\hline & 158 & 32 & 17600 & 4400 \\
\hline & 172 & 8 & $<1000$ & $<1000$ \\
\hline & 177 & 2 & 6800 & $<1000$ \\
\hline & 188 & 4 & 51200 & 10000 \\
\hline & 198 & 64 & 14800 & 18500 \\
\hline & 205 & 32 & 53500 & 5100 \\
\hline & 209 & 128 & 10000 & 6400 \\
\hline & 217 & 4 & 131000 & 12200 \\
\hline \multirow[t]{6}{*}{ Group 3} & 4 & 32 & 3300 & $<1000$ \\
\hline & 57 & 32 & 44800 & 4100 \\
\hline & 66 & 64 & 10000 & 1000 \\
\hline & 186 & 32 & 23500 & 5200 \\
\hline & 187 & 16 & 34400 & 5400 \\
\hline & 223 & $<2$ & $<1000$ & $<1000$ \\
\hline
\end{tabular}

K-186 to P1.7,1 (table I) was apparently caused by antibodies recognising the P1.1. subtype epitope because of its reaction with the two different P1.1 subtype strains (figure, panel $G$ ). When the blot was incubated with Empigen $\mathrm{BB}$ to partially refold the denatured proteins, binding to other class 1 proteins was also observed (panel $\mathrm{G}^{\prime}$ ). This indicated that, in addition to the Pl.1 specific activity the serum also contained antibodies against common conformational epitopes on the class 1 proteins.

All 28 sera were also studied for cross-reacting antibodies to the $\mathrm{P} 1.15$ protein. On blots, only five sera showed medium binding (scores $2-2.5$ ) to the P1.15 protein. Four of these belonged to group 2, the other was from patient $\mathrm{K}-186$, shown to have responses against common class 1 protein determinants. Two other sera in group 2 reacted with BacP1.15 in EIA with medium titres (2000 and 2100). One of those was from patient $\mathrm{K}-106$, whose serum reacted with all bacillar antigens. Thus, distinct cross-reactive antibodies were not detected by any of the methods.

\section{Kinetics of the class 1 response}

The low levels of class 1 protein antibodies observed in most of the late convalescent sera might be caused by a decline in the antibody response to infection as shown recently by Guttormsen et al. with purified P1.7,16 protein in EIA. ${ }^{34}$ Therefore, sera taken earlier after onset of disease from six of the vaccinees and six of the placebo-recipients were analysed. Only one of the placebo controls $(\mathrm{K}-177)$ had some anti-class 1 protein activity in the early convalescent samples as shown in table II. Of the three vaccinees in group 1 with high antibody levels in their late convalescent sera, K-15 and K-131, infected with vaccine-like strains, had higher levels against P1.7,16 and Bla-VR2 8-14 days after infection. The titres decreased in the ensuing years, but were still distinct 19-31 months after infection. In contrast, patient $\mathrm{K}-80$, infected with a B: $15:$ P1.12,13a strain, had no response in samples drawn 11 days (data not shown) or 45 days after onset of disease. However, 24 months after disease distinct P1.7,16 protein and VR2 antibody activities were found, indicating that this individual probably had been colonised with a meningococcal strain of subtype P1.16 which provided a booster to the initially vaccineinduced antibodies.

Vaccinee K-84 in group 2 had neither response in the early nor in the late convalescent samples, indicating that infection with the B:4:- strain did not increase the presumed initial P1.7,16-specific antibodies obtained by vaccination. Vaccinees K-217 and $\mathrm{K}-187$, infected with vaccine-like strains, showed an initial response to both BacP1.7,16 and VR2, followed by a decrease to low antibody levels 8-11 months after disease. None of the sera had anti-VR1 activity.

\section{Bacterial activity of the sera}

Serum bactericidal activity (SBA) was assayed with strain $44 / 76$ as a test for functionally relevant antibodies (table III). The test strain expressed low levels of the Opc protein, so Opc antibodies contributed little to the bactericidal titres. ${ }^{19.31}$ The four sera in group 1 with the highest levels of VR2-specific antibodies also had the highest SBA titres-128-512, geometric mean titre (GMT) 256. The sera in group 2 with no or low P1.7,16 activity had a GMT of $8 \cdot 6$. Only four of these sera had titres $\geqslant 64$. Among the group 3 sera, that from patient $\mathrm{K}-66$ with both a $\mathrm{P} 1.16$ and $\mathrm{P} 1.7$ response on blots was the only one with a corresponding high titre. This group had a GMT of 18. Except for that from patient $\mathrm{K}-209$, the high-titre sera in groups 2 and 3 were all from patients infected with $\mathrm{B}: 15: \mathrm{P} 1.7,16$ strains. In conclusion, the group 1 sera had 30 -fold and 14-fold higher SBA than those in groups 2 and 3, respectively.

\section{Antibodies against meningococcal surface antigens}

Antibody levels against meningococcal surface antigens in the late convalescent sera were quantitated in EIA with whole-cell preparations from B : $15:$ P1.7,16 and B: $15:$ P1.15 strains (table III). The levels measured with $B: 15: P 1.7,16$ cells were higher for the group 1 sera (GMT 136000) than for the sera in groups 2 and 3 with GMT 19300 and 9200, respectively. The corresponding GMT for B:15:P1.15 
cells were 30100,4600 and 1800 , respectively, indicating four-to-five-fold higher antibody level against the former antigen with a different subtype protein. The majority of sera with the highest titres $(>10000)$ to $\mathrm{B}: 15: \mathrm{P} 1.15$ were vaccinees and showed distinct antibody binding to serotype 15 protein on immunoblots (not shown). Only two of the 24 sera in groups 2 and 3 had titres $\geqslant 100000$ with $\mathrm{B}: 15: \mathrm{P} 1.7,16$ in contrast to all four sera in group 1 . These data indicated an immune response to several different antigens exposed on the meningococcal cell surface, with antibodies to the class 1 protein playing a major role.

\section{Discussion}

This report describes the antibody response to the meningococcal $\mathrm{P} 1.7,16$ class 1 protein and its two major VR1 (P1.7) and VR2 (P1.16) epitopes in sera from patients with systemic meningococcal disease. To our knowledge, this is the first attempt to quantitate the human antibody response to the VRs of the class 1 protein by subtype-specific antigens free of other meningococcal components. Previously, several investigators have studied the presence of anti-class 1 protein antibodies in human sera, by immunoblotting, ${ }^{15-17,35-37}$ gel immunoradioassay, ${ }^{38}$ inhibition studies with murine MAbs ${ }^{39-41}$ and EIA with purified P1.7,16. ${ }^{34}$

Both EIA and immunoblotting assays were used in this study to measure antibodies against P1.7,16 and its VRs in late convalescent sera. As detailed above, the antigens in the two methods were different in that the former assay employed various recombinant proteins, whereas different meningococcal strains were used in the latter method. The two methods gave identical results for the antibody responses with 22 $(79 \%)$ of the 28 sera. Four sera (group 1, table I) showed strong antibody binding to P1,7,16 and its VR2 epitope with both methods, whereas 18 sera (group 2, table I) displayed no or low antibody response to $\mathrm{P} 1.7,16$ by either method. No VR1 response was observed. The distinct binding of group 1 sera to the P1.7,16 proteins, denatured by SDS in both assays, as well as to Bla-VR2, suggested a strong antibody response to linear epitopes. An immunodominance of the VR2 (P1.16) epitope in healthy vaccinees measured by the same immunoblotting method has been reported previously. ${ }^{17,18}$

Six convalescent sera showed intermediate responses on blots but were negative in EIA (group 3, table I). Four of these had antibody specificities towards different determinants on P1.7,16. These responses included one serum with antibodies against VR2 (K-187), one with antibodies against both VR1 and VR2 (K-66), one reacting only with certain VR2subtype proteins (K-223), whereas one serum (K-4) bound only to P1·7,16 itself, but not to its VRs or to other class 1 proteins. The two remaining sera had antibodies reacting with subtypes $\mathrm{P} 1.12$ and P1.1. As the EIA antigens did not include peptide constructs corresponding to these subtypes, this assay was expected to be negative. Thus, the blotting method detected four sera with various responses to P1.7,16 that were not seen in EIA. This may indicate a higher sensitivity of the immunoblotting assay as seen for the sera from patients K-66 and K-187, or alternatively, as indicated by the binding patterns of sera $\mathrm{K}-4$ and $\mathrm{K}-223$, the antibodies may bind to conformational epitopes. These conformational epitopes were probably formed by partial refolding of the $\mathrm{P} 1.7,16$ protein during the assay and were distinct from those detected only when a renaturing detergent was used during the incubations. ${ }^{25}$

Three of the late sera with high levels of anti-P1.7,16 and anti-VR2 antibodies were from vaccinees (group 1 , table I) who fell ill with meningococcal disease during the Norwegian protection trial. ${ }^{20}$ Among the 99 original late sera tested--which included sera from 10 of the 12 vaccine failures - these three were the only high-responding sera found. As only one of the nonvaccinated patients showed a similar antibody level, the results indicated that infection led to increased vaccine-induced class 1 protein antibody levels as reported previously. ${ }^{17,34,37}$ Also the boosting effect of an unnoticed colonisation has to be considered, as demonstrated by the vaccinated patient $\mathrm{K}-80$, who had only low levels of anti-P1.7,16 antibodies 45 days after infection with a strain of a different subtype protein (B: 15:P1.12,13a), but a high level 24 months later (table II).

Comparison of the anti-P1.7,16 and anti-VR2 levels in early and late convalescent sera from vaccinees infected with vaccine-like strains showed a distinct fall in these activities with time (table II). These findings supported a previous demonstration of a fall in anti$\mathrm{P} 1 \cdot 7,16$ antibodies in convalescent sera to baseline levels 6 weeks -12 months after disease ${ }^{34}$ Similarly to that study, we also observed only IgG but no IgA or IgM antibodies against $P 1.7,16$. Although vaccination had primed the individuals for a strong antibody response on further contact with the P1.7,16 antigen, it was not sufficient to protect them against infection with vaccine-like strains, as previously reported. ${ }^{34,37}$

The non-vaccinated patients K-57, K-186 and K223 were infected with $\mathrm{B}: 15: \mathrm{P} 1.7, \mathrm{C}: 2 \mathrm{a}: \mathrm{P} 1.2$ and $\mathrm{B}: 4: \mathrm{P} 1.14$ strains, respectively (table I). Nevertheless, the blotting results showed that the main antibody activity in these sera was directed to the P1.12, P1.1 and P1.16 epitopes, respectively, unrelated to the subtype of the strains causing disease in these individuals. We believe that these antibody activities probably reflected colonisation in the period after disease by meningococci expressing other subtype proteins. As discussed above, the distinct P1.16 response in the late serum from vaccinee $\mathrm{K}-80$ indicated carriage of a P1.16 strain boosting vaccine-induced antibodies. From the rapid decline of class 1 protein antibodies it is likely that the new carrier strains must 
have been acquired not long before the late convalescent sera were drawn.

A recent study has shown that c. $25 \%$ of Norwegian teenagers are healthy carriers of meningococci, but that $<10 \%$ of the carrier isolates were representative of the strains responsible for most of the meningococcal disease in Norway. ${ }^{42}$ Generally, the possible colonising strains observed in the present study did not have subtypes similar to the strains causing disease. However, the strong $\mathrm{P} 1.16$ response in placebo control K-194, who was a culture-negative case, suggested that both the colonising and infecting strains expressed subtype P1.16. This assumption was supported by PCR and DNA sequence analysis of cerebrospinal fluid from this patient, drawing during the disease episode, demonstrating infection with a subtype P1.(7),16 strain (D. A. Caugant, personal communication). So, similar to the results found for volunteers receiving group B protein vaccines, ${ }^{37.43}$ group B infections did not appear to prevent later acquisition of meningococci.

The group 1 sera with the highest levels of P1.7,16and VR2-specific antibodies had 30-fold higher SBA than the group 2 sera with low or no response towards the corresponding antigens, and 14-fold higher SBA than those in group 3 with activities directed against various linear and conformational class 1 protein epitopes. After vaccination of mice, VR2 epitopes

\section{References}

1. Hitchcock P. Unified nomenclature for pathogenic Neisseria species. Clin Microbiol Rev 1989: 2: S64-S65.

2. Frasch CE. Zollinger WD, Poolman JT. Serotype antigens of Neisseria meningitidis and a proposed scheme for designation of serotypes. Rer Infect Dis 1985; 7: 504-510.

3. Barlow AK, Heckels JE, Clarke IN. The class 1 outer membrane protein of Neisseria meningitidis: gene sequence and structural and immunological similarities to gonococcal porins. Mol Microbiol 1989; 3: 131-139.

4. McGuinness B. Barlow AK. Clark IN et al. Deduced amino acid sequences of class 1 protein (PorA) from three strains of Neisseria meningitidis. Synthetic peptides define the epitopes responsible for serosubtype specificity. $J$ Exp Med 1990: 171: 1871-1882.

5. Maiden MCJ. Suker J. McKenna AJ, Bygraves JA. Feavers IM. Comparison of the class 1 outer membrane proteins of eight serological reference strains of Neisseria meningitidis. Mol Microbiol 1991: 5: 727-736.

6. Feavers IM. Heath AB, Bygraves JA, Maiden MCJ. Role of horizontal genetic exchange in the antigenic variation of the class 1 outer membrane protein of Neisseria meningitidis. Mol Microbiol 1992; 6: 489-495.

7. McGuinness BT. Lambden PR, Heckels JE. Class 1 outer membrane protein of Neisseria meningitidis: epitope analysis of the antigenic diversity between strains, implications for subtype definition and molecular epidemiology. Mol Microbiol 1993; 7: 505-514.

8. van der Ley P, Heckels JE, Virji M, Hoogerhout P, Poolman JT Topology of outer membrane porins in pathogenic Neisseria spp. Infect Immun 1991; 59: 2963-2971.

9. Saunders NB. Zollinger WD. Rao VB. A rapid and sensitive PCR strategy for amplification and sequencing of por $A$ from a single colony-forming unit of Neisseria meningitidis. Gene 1993: 137: 153-162.

10. Saukkonen K. Abdillahi H. Poolman JT, Leinonen M. Protective efficacy of monoclonal antibodies to class $I$ and class 3 outer membrane proteins of Neisseria meningitidis B : $15: \mathrm{P} 1.16$ in infant rat infection model: new prospects for vaccine development. Microb Pathog 1987; 3: 261-267. were found to induce higher SBA than those in VR1. ${ }^{13}$ Several studies have shown that antibodies directed to class 1 proteins, as well as to Opc protein, contribute to the bactericidal activity of human post-vaccination and convalescent sera. ${ }^{15,16,18,19,31,44}$ The test strain used in our bactericidal assays expressed only low levels of Opc protein, and, therefore, such antibodies added only marginally to the SBA observed. ${ }^{31}$ However, two patients (K-156 and K-209) with low levels of class 1 protein antibodies also had high SBA titres, so other antibody specificities must also account for the SBA.

In conclusion, the two methods gave concordant results for detecting P1.7,16 and VR2 responses in $79 \%$ of the sera studied. The immunoblotting method may allow demonstration of antibodies to some conformational epitopes not seen in EIA; however, the advantages of the EIA method are the possibility of quantitating the antibody response and the simplicity of performance. Also, the construction of other subtype variants offers the potential to further dissect the class 1 protein responses after infection and vaccination.

We thank Karin Bolstad, Anne Marie Klem, Elisabet Rønnild and Elina Winqvist for skilfull technical assistance. We are grateful to Drs P. H. Mäkelä and D. A. Caugant for critically reviewing the manuscript and to Drs J. T. Poolman and W. D. Zollinger for supplying the typing MAbs. Parts of this investigation received financial support from the WHO Global Programme for Vaccines.

11. Saukkonen K, Leinonen M, Abdillahi H, Poolman JT. Comparative evaluation of potential components for group B meningococcal vaccine by passive protection in the infant rat and in vitro bactericidal assay. Vaccine 1989; 7: 325-328.

12. van der Ley P, Poolman JT. Construction of a multivalent meningococcal vaccine strain based on the class 1 outer membrane protein. Infect Immun 1992; 60: 3156-3161

13. van der Ley $\mathbf{P}$, van der Biezen $\mathbf{J}$, Hohenstein $\mathbf{P}$, Peeters $C$, Poolman JT. Use of transformation to construct antigenic hybrids of the class 1 outer membrane protein in Neisseria meningitidis. Infect Immun 1993; 61: 4217-4224.

14. Christodoulides M, McGuinness BT, Heckels JE. Immunization with synthetic peptides containing epitopes of the class 1 outer-membrane protein of Neisseria meningitidis: production of bactericidal antibodies on immunization with a cyclic peptide. J Gen Microbiol 1993; 139: 1729-1738

15. Wedege E, Frøholm LO. Human antibody response to a group B serotype 2a meningococcal vaccine determined by immunoblotting. Infect Immun 1986; 51: 571-578.

16. Milagres LG, Ramos SR, Sacchi CT et al. Immune response of Brazilian children to a Neisseria meningitidis serogroup B outer membrane protein vaccine: comparison with efficacy. Infect Immun 1994; 62: 4419-4424.

17. Wedege E, Bjune G, Frøholm LO, Høiby EA, Rosenqvist E. Immunoblotting studies of vaccinee and patient sera from a Norwegian serogroup B meningococcal vaccination trial. NIPH Ann 1991; 14: 183-186.

18. Rosenquist E, Høiby EA, Wedege $\mathrm{E}$ et al. A new variant of serosubtype P1.16 in Neisseria meningitidis from Norway, associated with increased resistance to bactericidal antibodies induced by a serogroup B outer membrane protein vaccine. Microb Pathog 1993; 15: 197-205.

19. Høiby EA, Rosenqvist E. Frøholm LO et al. Bactericidal antibodies after vaccination with the Norwegian meningococcal serogroup B outer membrane vesicle vaccine: a brief survey. NIPH Ann 1991; 14: 147-156.

20. Bjune G, Høiby EA, Grønnesby JK et al. Effect of outer membrane vesicle vaccine against group $B$ meningococcal disease in Norway. Lancet 1991; 338: 1093-1096. 
21. Nurminen M, Butcher S, Idänpään-Heikkilä I et al. The class 1 outer membrane protein of Neisseria meningitidis produced in Bacillus subtilis can give rise to protective immunity. $\mathrm{Mol}$ Microbiol 1992; 6: 2499-2506.

22. Wedege E, Høiby EA, Rosenqvist E, Frøholm LO. Serotyping and subtyping of Neisseria meningitidis isolates by coagglutination, dot-blotting and ELISA. $J$ Med Microbiol 1990; 31: 195-201.

23. Garred P, Michaelsen TE, Bjune G, Thiel A, Svejgaard A. A low serum concentration of mannan-binding protein is not associated with serogroup B or C meningococcal disease. Scand J Immunol 1993; 37: 468-470.

24. Mandrell RE, Zollinger WD. Use of a zwitterionic detergent for the restoration of the antibody-binding capacity of electroblotted meningococcal outer membrane proteins. $J$ Immunol Methods 1984; 67: 1-11.

25. Wedege E, Bryn K, Frøholm LO. Restoration of antibody binding to blotted meningococcal outer membrane proteins using various detergents. J Immunol Methods 1988; 113 : $51-59$.

26. Høiby EA, Bjune G, Frøholm LO et al. The Norwegian meningococcal serogroup B outer membrane vesicle vaccine protection trials: case tracing, meningococcal antigen detection and serological diagnosis. NIPH Ann 1991; 14: $107-123$.

27. Idänpään-Heikkilä I, Muttilainen S, Wahlstrøm E et al. The antibody response to a prototype liposome vaccine containing Neisseria meningitidis outer membrane protein $\mathrm{P} 1$ produced in Bacillus subtilis. Vaccine 1995 (in press).

28. Ambler RP, Coulson AFW, Frère JM et al. A standard numbering scheme for the class A $\beta$-lactamases. Biochem $J$ 1991; 276: 269-270.

29. Palva I, Sarvas M, Lehtovaara P, Sibakov M, Kääriäinen L. Secretion of Escherichia coli $\beta$-lactamase from Bacillus subtilis by the aid of $\alpha$-amylase signal sequence. Proc Natl Acad Sci USA 1982; 79: 5582-5586.

30. Mocca LF, Frasch CE. Sodium dodecyl sulfate-polyacrylamide gel typing system for characterization of Neisseria meningitidis isolates. J Clin Microbiol 1982; 16: 240-244.

31. Rosenqvist E, Høiby EA, Wedege E, Kusceck B, Achtman M. The 5C protein of Neisseria meningitidis is highly immunogenic in humans and induces bactericidal antibodies. J Infect Dis 1993; 167: 1065-1073.

32. Wedege E, Kolberg J, Delvig A et al. Emergence of a new virulent clone within the ET-5 complex of serogroup B meningococci in Norway. Clin Diagn Lab Immunol 1995; 2: 317-321.

33. Wedege E, Dalseg R, Caugant DA, Poolman JT, Frøholm LO. Expression of an inaccessible P1.7 subtype epitope on meningococcal class 1 proteins. J Med Microbiol $1993 ; 38$ : 23-28.
34. Guttormsen H-K, Wetzler LM, Solberg CO. Humoral immune response to class 1 outer membrane protein during the course of meningococcal disease. Infect Immun 1994; 62: 1437-1443.

35. Zollinger WD, Mandrell RE. Studies of the human antibody response to specific meningococcal outer membrane proteins of serotypes 2 and 15. Med Trop 1983; 43: 143-147.

36. Mæland JA, Wedege E. Serum antibodies to cross-reactive Neisseria outer membrane antigens in healthy persons and patients with meningococcal disease. APMIS 1989; 97 : 774-780.

37. Zollinger WD, Boslego JW, Moran EE, Brandt BL. Effect of vaccination with meningococcal outer membrane protein vaccine on subsequent antibody response to carriage and natural infection. In: Conde-Glez CJ, Morse S, Rice P et al. (eds) Pathobiology and immunology of Neisseriaceae. Instituto Nacional de Salud Publica. 1994: 954-960.

38. Poolman JT, Hopman CTP, Zanen HC. Immunogenicity of meningococcal antigens as detected in patient sera. Infect Immun 1983; 40: 398-406.

39. Mandrell RE, Zollinger WD. Human immune response to meningococcal outer membrane protein epitopes after natural infection or vaccination. Infect Immun 1989; 57: $1590-1598$.

40. Orren A, Warren RE, Potter PC, Jones AM, Lachmann PJ, Poolman JT. Antibodies to meningococcal class 1 outer membrane proteins in South African complement-deficient and complement-sufficient subjects. Infect Immun 1992; 60: $4510-4516$.

41. Peeters CCAM, Schuller M, Westdijk J, Poolman JT. Specificity of bactericidal antibody responses in volunteers immunized with meningococcal B:15:P1.7,16 outer membrane proteins complexed to $C$ polysaccharide and in patients infected with B: 15:P1.7, 16. In: Conde-Glez CJ, Morse S, Rice $\mathrm{P}$ et al. (eds) Pathobiology and immunology of Neisseriaceae. Instituto Nacional de Salud Publica. 1994: 880-887.

42. Caugant DA, Høiby EA, Magnus $\mathbf{P}$ et al. Asymptomatic carriage of Neisseria meningitidis in a randomly sampled population. J Clin Microbiol 1994; 32: 323-330.

43. Rosenqvist E, Bjune G, Feiring B et al. Changes in carrier status of Neisseria meningitidis in teenagers during a group $\mathrm{B}$ outer membrane vaccination trial in Norway. In: CondeGlez CJ, Morse S, Rice P et al. (eds) Pathobiology and immunology of Neisseriaceae. Instituto Nacional de Salud Publica. 1994: 895-901.

44. Zollinger WD, Moran E. Meningococcal vaccines - present and future. Trans R Soc Trop Med Hyg 1991; 85 Suppl 1: $37-43$. 